\title{
Enhanced synthesis of andrographolide by Aspergillus niger and Penicillium expansum elicitors in cell suspension culture of Andrographis paniculata (Burm. f.) Nees
}

\author{
Moinuddin M A Vakil and Vijay D Mendhulkar
}

\begin{abstract}
Background: Andrographis paniculata (Burm. f.) Nees is an important medicinal plant which has enormous applications in pharmaceutical industries. Cell suspension culture of Andrographis paniculata (Burm. f.) Nees. was treated with Aspergillus niger and Penicillium expansum elicitors to enhance the synthesis of andrographolide, the bioactive constituent of $A$. paniculata.

Result: The elicitation treatment with fungal elicitors (A. niger and P. expansum) was observed to be most suitable for eliciting andrographolide production in the culture. The quantification of andrographolide was done using High Performance Liquid Chromatography (HPLC) technique. A. niger extract ( $1.5 \mathrm{ml}$ with10 days treatment duration) revealed 6.94 fold increase in andrographolide content $(132 \mu \mathrm{g})$ which was higher than the control $(19 \mu \mathrm{g})$. P. expansum elicitor ( $0.6 \%$ with 8 days treatment duration) could reveal 6.23 fold enhancement in andrographolide content $(81.0 \mu \mathrm{g})$ over control $(13 \mu \mathrm{g})$.
\end{abstract}

Conclusion: The results obtained reveal that the longer treatment duration is most favorable for the elicitation of andrographolide using both the fungal elicitors.

Keywords: Active constituents; Fungal elicitors; HPLC analysis; Secondary metabolites; Tissue culture techniques

\section{Background}

Plant cell culture is considered as a useful technique for the large scale production of plant secondary metabolites under in vitro level beside its utility for micropropagation. The production of these bioactive metabolites can be achieved by elicitation, cell immobilization, permeabilization (Brodelius et al. 1989; Mendhulkar et al. 2009), alteration in media composition etc.

Andrographis paniculata Nees. is commonly known as 'Kalmegh' in India and as a medicinal plant belongs to the family Acanthaceae. The plant is recommended for its drug utility in Indian Pharmacopoeia and widely used in Ayurveda, Unani, Siddha and Homeopathy systems of medicines. The plant is reported to possess terpenoids and flavonoids. The major terpenoids viz. 14-deoxy-11-

\footnotetext{
* Correspondence: m.mvakil@yahoo.com

Department of Botany, The Institute of Science, 15, Madam Cama Road, Mumbai 4000 32, India
}

oxoandrographolide, 14-deoxy-11, 12-didehydroandrographolide and 14-deoxyandrographolide andrographolide are the active constituents of this plant. The main active constituent is andrographolide which is reported to possess liver stimulant, astringent, anodyne, tonic and alexipharmic properties and useful in dysentery, cholera, diabetes, consumption, influenza, bronchitis, swellings, itches, piles and gonorrhea (Zhao and Frang 1991). The most significant pharmaceutical properties of this plant are anticancerous (Kumar et al. 2004) and anti-HIV (Calabrese et al. 2000).

The qualitative and quantitative improvement of biologically active compounds by plant cell, tissue and organ culture have been used as an alternative source for the production of important bioactive secondary metabolites using different strategies of metabolic engineering. The biotechnological production of valuable secondary metabolites in plant cell or organ cultures is a good alternative to the

\section{实}


extraction of whole plant material because many plants of high medicinal products are difficult to cultivate. The attractive concepts in the scaling up technology of natural products are enhancement of secondary metabolites and use of biological and chemical elicitors. It has been found that plants elicit the same response when come in contact with the compounds of the pathogen as attacked by the pathogen itself. These compounds are known as elicitors. Taxol, an anticancer drug produced from cell cultures of Taxus plant has been successfully industrialized for commercial purpose. Ajmalicine and serpentine from Catharanthus roseus, Caffeine from Coffea Arabica, Ginsenoside from Panaxginseg and Vomilenine from Rauwolfia serpentine have been produced from cell cultures (Bojwani and Razdan 1996). It has also been successfully experimented for the compounds like Cardio active glycosides in Digitalis purpurea, L-Dopa in Mucuna prurience, Berberine in Coptis japonica, diosgenin in Dioscorea deltoid and capsaicin in Capsicum frutescent (Masanaru 1994; Vanisree et al. 2004).

According to WHO, Angiospermic plants contribute $11 \%$ of 252 drugs which are considered as basic and essential drugs (Rates 2001). Plants derived drugs in western countries have a huge market value. Prescription drugs containing photochemical were valued at more than US $\$ 30$ billion in 2002 in the USA alone (Raskin, et al. 2002). The average yield of these plants are about 2.5 tonnes/ ha and it is sold in Indian market at the rate of Rs.15-20 / Kg. (Purohit and Vyas 2004). In Indian market, the rate of $A$. paniculata crude powder is Rs. $1800 /$ - per quintal. This powder is used in Ayurvedic and Homeopathic formulations.

Andrographis paniculata (Kalmegh) forms the part of number of drug formulations available in Indian market. It is a major constituent of SG-1 Switradilepa which is an Ayurvedic drug effective in treating vitiligo -a dermatological disease. It is also used in certain homoeopathic preparations such as Livo -10 (syrup) which is used in various functional derangements of liver and gastro intestinal system, acute and chronic hepatitis, poor digestion, constipation and Paroxysmal pain in abdomen. It is one of the important constituents of herbal formulations, Purim, a blood purifier (capsule and syrup); Liv fit, a hepatitis virus DNA replication inhibitor drug and a multiple disorder curetting drug, Livo Plus. All these drugs are available in Indian market.

In the present work, elicitation of andrographolide compound was experimentally worked out using two fungal elicitors viz. Aspergillus niger and Penicillium expansum in Andrographis paniculata (Burm.f.) Nees. cell suspension culture.

\section{Methods}

Cell suspension culture

The calli obtained using leaf explants of Andrographis paniculata on MS media supplemented with 2,4-D: BAP
(1.0:0.5 mg/l) were transferred into liquid Murashige and Skoog 1962 media supplemented with same hormonal combination and concentration except agar (Figure 1). The cell suspension culture was grown in gyratory shaker with 120 r.p.m. at $25 \pm 1^{\circ} \mathrm{C}$ under dark condition for 30 days. The cell growth phase was determined using colorimetric method.

\section{Cell viability}

The cell viability in 25 days old suspension culture was determined by Guava Via Count assay using Guava Easy CD4 System. For cell viability assay, $10 \mu \mathrm{l}$ of suspension culture was taken in eppendorf tube, added $190 \mu$ l of via count solution (viability counting solution) and incubated for $5 \mathrm{~min}$ at room temperature. The analysis was performed using Cytosoft software for Guava Via Count (Guava ViaCount Reagent 2006). The results were obtained in the form of viable cell count and total cell count (both in number of cells $/ \mathrm{ml}$ ) and the percent viability.

\section{Fungal culture}

Aspergillus niger and Penicillium expansum used for elicitation were obtained from Department of Microbiology (The Institute of Science, Mumbai). The fungal cultures were first maintained separately as slants in culture tubes containing Potato dextrose agar (PDA) medium. The culture medium composition is as follows in $\mathrm{g} / \mathrm{L}$ : Peeled potatoes (200 g), Dextrose (20 g), Yeast extract (0.1 g), Agar (20 g), Twin $80(0.5 \%)$ and $\mathrm{pH}$ was adjusted to 5 . After two weeks, both the fungi were grown separately in $250 \mathrm{ml}$ flasks containing $100 \mathrm{ml}$ of Potato dextrose broth (PDB medium) under dark and static condition at room temperature for three weeks. PDB was prepared similarly without agar which was used to grow fungal mycelia for the preparation of elicitor.

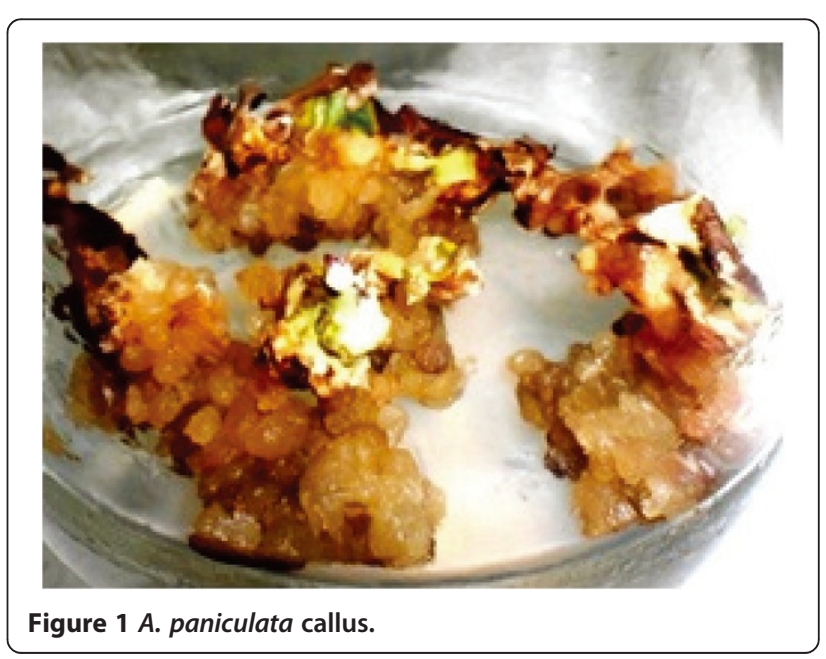




\section{Preparation of Aspergillus niger elicitor}

Aspergillus niger cultures grown in $250 \mathrm{ml}$ flasks containing $100 \mathrm{ml}$ of potato-dextrose broth (PDB medium) were harvested after three weeks. The fungal cultures were autoclaved along with the media at 15 psi for $20 \mathrm{~min}$. After autoclaving, the fungal mycelial mat floating on the surface of the medium was removed carefully and washed several times with distilled water and allowed to dry in hot air oven at $40^{\circ} \mathrm{C}$ to obtain constant dry weight. The dried mycelial mat was crushed into powder using mortar and pestle and used as dry cell powder (DCP).

\section{Extraction of DCP}

Five $\mathrm{g}$ of DCP was added to $500 \mathrm{ml}$ of acidified distilled water ( $\mathrm{pH} \mathrm{2}$ ) and boiled for $45 \mathrm{~min}$. After boiling, the culture was filtered and the $\mathrm{pH}$ of the filtrate was adjusted to 5 using $1 \mathrm{~N} \mathrm{NaOH}$ and the volume was adjusted to $500 \mathrm{ml}$ with D.W. This solution was autoclaved at $15 \mathrm{psi}$ for $20 \mathrm{~min}$. and used as an elicitor without further purification. $1 \mathrm{ml}, 1.5 \mathrm{ml}$ and $2 \mathrm{ml}$ of this fungal elicitor were added in Dippy's Jar containing the A. paniculata cell suspension. The treatments of fungal elicitor were administered for the duration of 4 days, 7 days and 10 days.

\section{Preparation of Penicillium expansum elicitor}

Penicillium expansum mycelial mat obtained after three weeks was autoclaved, separated and washed several times with demineralized water. The mycelial residue was resuspended in an amount of demineralized water equal to that of the filtrate and homogenized. This homogenate was autoclaved again and used in the concentrations, $0.3 \%$, $0.6 \%$ and $1.2 \%$. The treatment was administered in Dippy's Jar containing Andrographis paniculata cell suspension. Each of these fungal concentrations was subjected for the treatment duration of 2 days, 5 days and 8 days. The polysaccharide content in the DCP extract of Aspergillus niger and Penicillium expansum homogenate was determined by the phenol sulfuric acid method (Sadasivam and Manickam 2005) using glucose as the standard.

\section{Analytical methods}

After each experiment, cell suspensions were filtered and washed several times with distilled water and filtered cells were dried in oven at $50^{\circ} \mathrm{C}$ to a constant weight. Completely oven dried samples of all treatments were powdered using mortar and pestle. Amount of $150 \mathrm{mg}$ of was taken from each powdered sample was and sonicated using $2 \mathrm{~mm}$ probe for $10 \mathrm{~min}$ with pulse rate operating at $10 \mathrm{sec}$. on and $2 \mathrm{sec}$. off, amplitude $20 \%$ in $1.5 \mathrm{ml}$ of methanol using Sonics Vibra Cell (VCX 130) instrument. After sonication the extract was centrifuged at $5000 \mathrm{rpm}$ for $5 \mathrm{~min}$. the supernatant was transferred into $2 \mathrm{ml}$ eppendorf tubes and the final volume was adjusted to $2 \mathrm{ml}$ with methanol (HPLC grade). This extract was used for HPLC analysis. For HPLC analysis, $2 \mathrm{ml}$ of methanol extract was filtered with $0.45 \mathrm{~mm}$ nylon syringe filter (Tarsons). The filtered extracts were stored in clean HPLC vials before injection into HPLC system.

Andrographolide content in the samples was detected and quantified by HPLC system, supplied by Agilent Technologies comprising 1100/1200 Column Thermostat, 1200 Variable Wavelength Detector, 1100/1200 Quaternary Pump and 100/1200 Thermostatted Autosampler. Column of ZORBAX 300SB-C18, dimensions $4.6 \times$ $150 \mathrm{~mm}$ ("Agilent Technologies", USA) with particle size of $5 \mu \mathrm{m}$ were used. The column was operated in the reverse phase mode. The compound, andrographolide in the samples was detected at $223 \mathrm{~nm}$ wavelength. All the solvents used were of HPLC grade ("Fisher Scientific", India and Sigma - Aldrich). The purified RO water (Analytica, India) was used for preparing mobile phase. All the samples were filtered through $0.45 \mathrm{~mm}$ membrane filter. The mobile phase consisted of a mixture of Acetonitrile: $0.1 \%$ $(\mathrm{v} / \mathrm{v})$ phosphoric acid in water (40:60, v/v) under isocratic conditions for analysis of andrographolide. $20 \mu \mathrm{l}$ of each sample was used for injection and the flow rate was $1.0 \mathrm{ml} / \mathrm{min}$. and the run was continued for 8 minutes for column $4.6 \times 150 \mathrm{~mm}$ for all samples for complete resolution and detection of andrographolide. The $20 \mathrm{ppm}$ standard solution of andrographolide was prepared in HPLC grade methanol and $20 \mu \mathrm{l}$ from $20 \mathrm{ppm}$ solution was used for injection. Injection volume of $20 \mu \mathrm{l}$ was kept constant during the experimentation. Identification of andrographolide in cell samples was confirmed by retention time, co-chromatography with the standard and peak purity by wavelength.

\section{Statistical analysis of data}

All the data obtained is represented as mean $\pm \mathrm{SD}$ of triplicate of experiments using Microsoft Excel XP.

\section{Results and discussion Cell viability}

The cell viability of cell suspension culture of Andrographis paniculata was recorded to be $86 \%$ using Guava Easy CD4 System (Table 1). This result indicates that the conditions for cell suspension culture are quite favorable. The same incubation condition was applied for further experimental cultures.

\section{Estimation of total carbohydrate content by phenol sulphuric acid method}

To determine the dose concentration of each elicitor, Phenol sulphuric acid method was used to find out the total carbohydrate content present in each elicitor which revealed $9.8 \mathrm{mg}, 14.7 \mathrm{mg}$ and $19.66 \mathrm{mg}$ of fungal poly- 
Table 1 Cell viability in Andrographis paniculata suspension culture after $\mathbf{3 0}$ days incubation in gyratory shaker at $110 \mathrm{rpm}$ at $25+2^{\circ} \mathrm{C}$

\begin{tabular}{lcc}
\hline Sample ID & Cell viability $\%$ & Mean \% \\
\hline A. paniculata 1 & $86 \%$ & $86 \%$ \\
A. paniculata 2 & $88 \%$ & \\
A. paniculata 3 & $82 \%$ & \\
A. paniculata 4 & $90 \%$ & \\
A. paniculata 5 & $84 \%$ & \\
\hline
\end{tabular}

saccharide $\mathrm{l}^{-1}$ in $1.0 \mathrm{ml}, 1.5 \mathrm{ml}$ and $2.0 \mathrm{ml}$ of Aspergillus niger elicitor respectively. Similarly, $0.3 \%, 0.6 \%$ and $1.2 \%$ of the homogenate of Penicillium expansum were equivalent to $4.08 \mathrm{mg}, 8.16 \mathrm{mg}$ and16.32 $\mathrm{mg}$ of fungal polysaccharide $\mathrm{l}^{-1}$ respectively.

\section{HPLC result}

A simple, isocratic, selective reversed phase-liquid chromatographic method was developed for the determination of andrographolide in the extracts of the cell suspension cultures of Andrographis paniculata (Burm. f.) Nees. In this method, a satisfactory separation was obtained with a mobile phase consisting of Acetonitrile: $0.1 \%$ $(\mathrm{v} / \mathrm{v})$ phosphoric acid in water (40:60, v/v). Quantification was achieved with UV detection at $223 \mathrm{~nm}$ based on peak area (Figure 2). The average retention time with \pm standard deviation was found to be $2.41 \pm 0.05$ min and $2.33 \pm$ $0.017 \mathrm{~min}$ for andrographolide in Aspergillus niger and Penicillium expansum treated samples, respectively.

Effect of Aspergillus niger elicitors on quantitative enhancement in andrographolide content

Figure 3 display the elicitation of andrographolide by Aspergillus niger elicitors in cell suspension culture of
Andrographis paniculata. In 4 days and 7 days treatment duration, $1 \mathrm{ml}$ of $A$. niger extract was found to be most positive concentration for eliciting andrographolide compound. The estimated quantity of andrographolide was $52.0 \mu \mathrm{g} / \mathrm{g}$ and $331.0 \mu \mathrm{g} / \mathrm{g}$ in 4 days and 7 days treatment duration, respectively, which showed 2.47 and 3.76 fold increase over their respective controls.

Increasing doses of $A$. niger extract with 4 days treatment duration had moderate effect on andrographolide content compared to respective control (Table 2). The concentration of $1.5 \mathrm{ml}$ of $A$. niger extract produced $45.0 \mu \mathrm{g} / \mathrm{g}$ of andrographolide content which was slightly higher over the control and $2 \mathrm{ml}$ showed $19.0 \mu \mathrm{g} / \mathrm{g}$ of andrographolide, a less quantity compared to respective control $(21.0 \mu \mathrm{g} / \mathrm{g})$. For 7 days treatment duration, only $1 \mathrm{ml}$ dose was found to be effective in eliciting andrographolide content $(331.0 \mu \mathrm{g} / \mathrm{g})$ whereas, $1.5 \mathrm{ml}$ concentration revealed negative response. Two $\mathrm{ml}$ extract treatment indicates negligible quantity of andrographolide $(8.0 \mu \mathrm{g} / \mathrm{g})$ i.e. lower than control $(88.0 \mu \mathrm{g} / \mathrm{g})$.

The 10 days treatment duration proved to be most favorable as it indicates enhancement in the content of andrographolide in $1 \mathrm{ml}$ of $A$. niger extract. Increased concentration of $A$. niger extract $(1.5 \mathrm{ml})$, revealed remarkable increase in andrographolide content $(132.0 \mu \mathrm{g} / \mathrm{g})$. However, further increase in the concentration to $2 \mathrm{ml}$, ceased the production of andrographolide to $47.0 \mu \mathrm{g} / \mathrm{g}$. The results obtained in the present study are in agreement with the findings of other researchers which suggest that the lower dose of $A$. niger extract is effective in eliciting the target compound (Ibrahim et al. 2007; Fu and Lu 1999). It is reported that $2.5 \mathrm{ml}$ of fungal extract prepared from fungal strain (F5) which was isolated from inner bark of 15-20-m high Taxus chinensis tree showed enhanced paclitaxel content on 14 days of treatment exposure in T. chinensis cell suspension culture (Zhang et al. 2000).

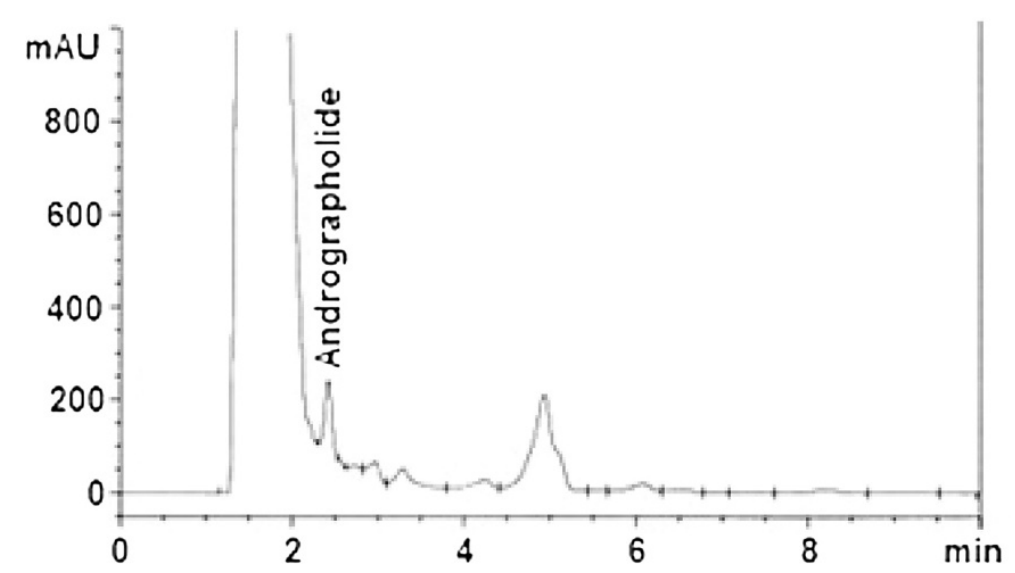

Figure 2 HPLC chromatogram showing the chromatographic separation of andrographolide from other compounds of the fungal elicited cell suspension cultures extract of $A$. paniculata. 


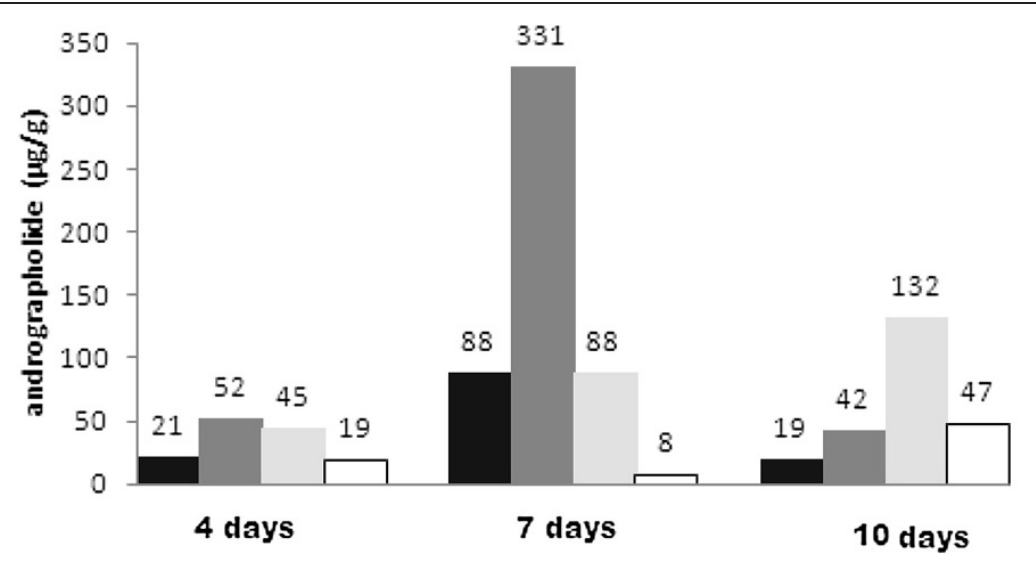

Figure 3 Effect of Aspergillus niger on andrographolide synthesis in A. paniculata cell suspension culture.

Similarly, $2 \mathrm{ml}$ extract of $A$. niger per $100 \mathrm{ml}$ of cell suspension culture enhanced oleandrin yield up to $3.164 \mathrm{mg} \mathrm{l}^{-1}$. It was 8.8 fold higher than that of control $\left(0.31 \mathrm{mg} \mathrm{l}^{-1}\right)$ in 25 days old culture of Nerium oleander (Ibrahim et al. 2007).

Table 2 Effect of fungal elicitors on andrographolide production (Mean \pm SD)

\begin{tabular}{|c|c|c|c|c|}
\hline $\begin{array}{l}\text { Name of } \\
\text { elicitors }\end{array}$ & $\begin{array}{l}\text { Treatment } \\
\text { durations }\end{array}$ & $\begin{array}{c}\text { Concentrations } \\
\text { of elicitor }\end{array}$ & $\begin{array}{l}\text { Andrographolide } \\
\text { content in } \mu \mathrm{g} / \mathrm{g}\end{array}$ & $\begin{array}{c}\text { Fold } \\
\text { increase }\end{array}$ \\
\hline & & Control & $21.0 \pm 0.74$ & \\
\hline \multirow{12}{*}{$\begin{array}{l}\text { Aspergillus } \\
\text { niger }\end{array}$} & 4 days & $1.0 \mathrm{ml}$ & $52.0 \pm 0.13$ & 2.47 \\
\hline & & $1.5 \mathrm{ml}$ & $45.0 \pm 0.61$ & 2.14 \\
\hline & & $2.0 \mathrm{ml}$ & $19.0 \pm 0.3$ & - \\
\hline & & Control & $88.0 \pm 0.37$ & \\
\hline & 7 days & $1.0 \mathrm{ml}$ & $331.0 \pm 0.43$ & 3.76 \\
\hline & & $1.5 \mathrm{ml}$ & $88.0 \pm 0.34$ & - \\
\hline & & $2.0 \mathrm{ml}$ & $8.0 \pm 0.70$ & - \\
\hline & & Control & $19.0 \pm 0.13$ & \\
\hline & 10 days & $1.0 \mathrm{ml}$ & $42.0 \pm 0.94$ & 2.21 \\
\hline & & $1.5 \mathrm{ml}$ & $132.0 \pm 0.62$ & 6.94 \\
\hline & & $2.0 \mathrm{ml}$ & $47.0 \pm 0.74$ & 2.47 \\
\hline & & Control & $10.0 \pm 0.11$ & \\
\hline \multirow{11}{*}{$\begin{array}{l}\text { Penicillium } \\
\text { expansum }\end{array}$} & 2 days & $0.3 \%$ & $12.0 \pm 0.84$ & 1.2 \\
\hline & & $0.6 \%$ & $22.0 \pm 0.83$ & 2.2 \\
\hline & & $1.2 \%$ & $16.0 \pm 0.69$ & 1.6 \\
\hline & & Cont. & $24.0 \pm 0.28$ & \\
\hline & 5 days & $0.3 \%$ & $22.0 \pm 0.86$ & - \\
\hline & & $0.6 \%$ & $35.0 \pm 0.95$ & 1.45 \\
\hline & & $1.2 \%$ & $32.0 \pm 0.11$ & 1.33 \\
\hline & & Cont. & $13.0 \pm 0.45$ & \\
\hline & 8 days & $0.3 \%$ & $29.0 \pm 0.14$ & 2.23 \\
\hline & & $0.6 \%$ & $81.0 \pm 0.74$ & 6.23 \\
\hline & & $1.2 \%$ & $15.0 \pm 0.21$ & 1.15 \\
\hline
\end{tabular}

Effect of Penicillium expansum elicitors on quantitative enhancement in andrographolide content

Table 2 and Figure 4 illustrate the effect of different concentrations of $P$. expansum on andrographolide production for different treatment durations in cell suspension culture of Andrographis paniculata. In 2 and 5 days treatment duration, $0.6 \% P$. expansum extract was found most suitable concentration for andrographolide elicitation which yielded $22.0 \mu \mathrm{g} / \mathrm{g}$ and $35.0 \mu \mathrm{g} / \mathrm{g}$ of andrographolide respectively. These enhancements were 2.2 and 1.45 fold higher than their respective controls. Andrographolide yield enhanced maximum as $81.0 \mu \mathrm{g} / \mathrm{g}$, when treated with $0.6 \% P$. expansum extract for 8 days. It was 6.23 fold higher than the control which reached up to $13.0 \mu \mathrm{g} / \mathrm{g}$ for the same culture period.

Similar results have been obtained in Beta vulgaris hairy root cultures in which the lower concentrations of Penicillium notatum (5\% and 7\%) have yielded $40.5 \mathrm{mg} / \mathrm{l}$ and $46.2 \mathrm{mg} / \mathrm{l}$ of betalain respectively compared to control $24.5 \mathrm{mg} / \mathrm{l}$ when exposed to 3 days incubation period (Savitha et al. 2006). The further enhancement was achieved up to $92.0 \mathrm{mg} / \mathrm{l}$ and $97.2 \mathrm{mg} / \mathrm{l}$ of betalain in $5 \%$ and $7 \%$ concentration of Penicillium notatum elicitor treated samples on 7 days treatment period over control (43.2 $\mathrm{mg} / \mathrm{l})$.

Aspergillus niger elicitor (1.5 ml, 10 days duration) showed 6.94 fold enhancement in andrographolide content which was higher among other studied concentrations and treatment durations of $A$. niger. P. expansum elicitor showed 6.23 fold enhancements in andrographolide content when $0.6 \%$ concentration of $P$. expansum for 8 days treatment duration was administered. This concentration and incubation period was superior to other studied concentrations and incubation periods for $P$. expansum elicitor. The elicitation effect of $A$. niger was higher (6.94 fold increase in andrographolide content) compared to $P$. expansum (6.23 fold increase) in $A$. paniculata cell suspension culture when treated with 1.5 


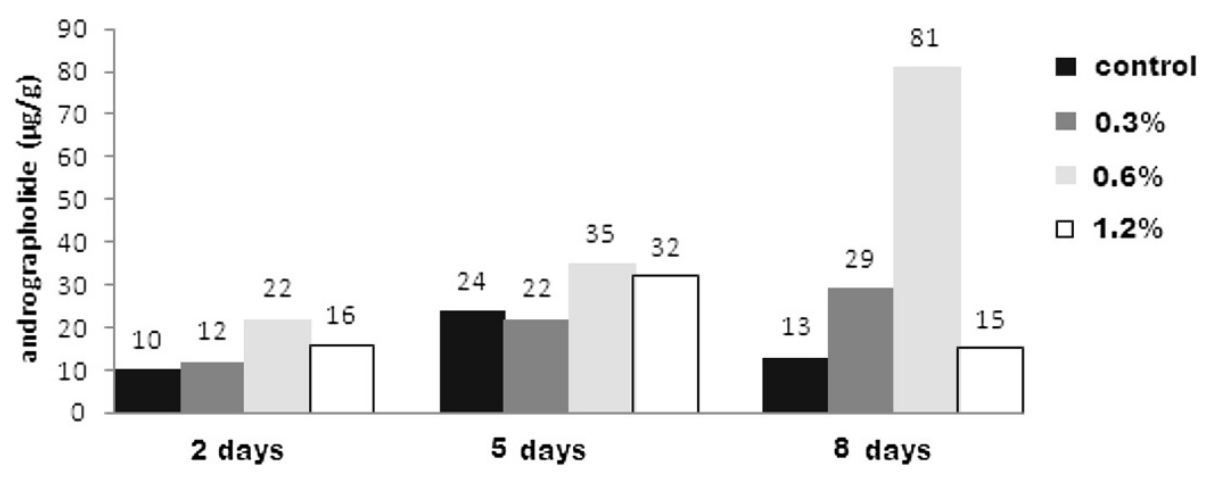

Figure 4 Effect of Penicillium expansum on andrographolide synthesis in A. paniculata cell suspension culture.

$\mathrm{ml}$ of $A$. niger extract for 10 days and $0.6 \%$ concentration of $P$. expansum for 8 days treatment duration respectively (Figure 5).

Plant cells are interacted with elicitors at metabolic level. Plants on pathogen attack or treatment of plants with elicitor causes an array of defense reaction which includes the accumulation of a wide range of secondary metabolites at enhanced level. Various mechanisms have been hypothesized for mechanism of elicitation. The binding of elicitor to a plasma membrane receptor is hypothesized by some researcher for elicitation process (Cheong and Hahn 1991; Cosio et al. 1990; Basse et al. 1993; Nürnberger et al. 1994; Braun and Walker 1996 and Hanania and Avni 1997). During the process of elicitation, elicitors are recognized by specific receptors in the plant cell which are localized either on the cell surface for a number of fungal elicitors or within the cell for certain bacterial elicitors (Ebel and Scheel 1997; Yang and Gabriel 1995 and Ackerveken et al. 1996). These receptors initiate signaling processes that activate plant defenses. The pathogen-plant interaction can be divided

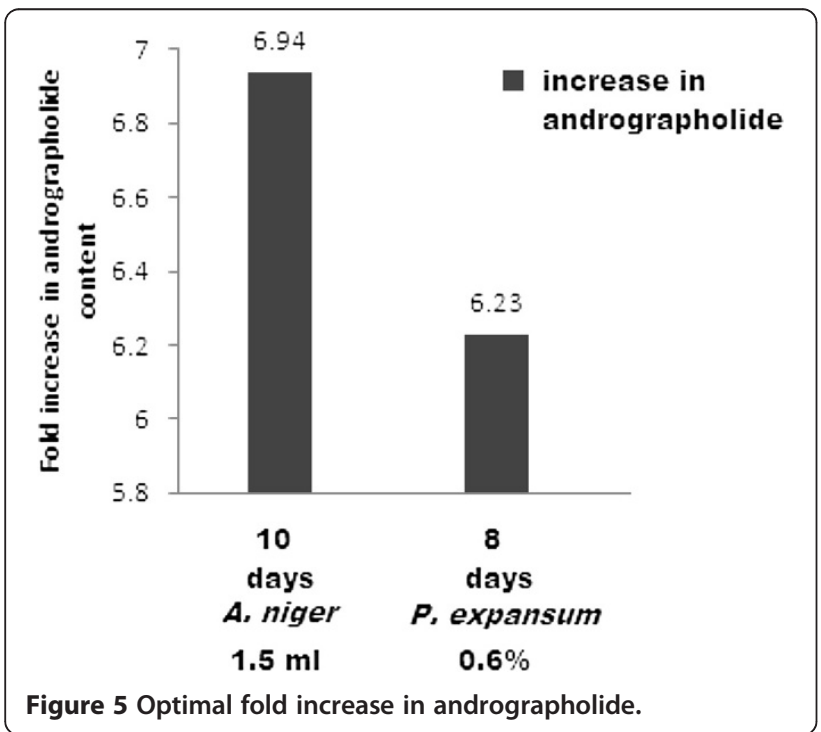

into two different categories viz. host or race-specific resistance and non-host interaction. In case of the host or race-specific resistance, the pathogen interacts with a potential host that has acquired a resistance gene (R-gene). In case of the non-host interaction, the plant recognizes potentially pathogenic microbes by the means of conserved structures which are present in a wide variety of microbes. These structures are known as pathogenassociated molecular patterns (PAMP).

Many elicitors such as chitin, xyloglucans, chitosan, hglucan and oligogalacturonide are known to induce phytoalexins in different plant systems, suggesting that different plants possess some common receptors to sense these signals. According to Gelli et al. (1997), $\mathrm{Ca}^{2+}$ influx into the cytoplasm from extracellular environment and intracellular $\mathrm{Ca}^{2+}$ reservoir is involved in elicitation process. For example, in parsley cells, an elicitor- responsive calcium channel has been identified and characterized and a transient influx of calcium has been found after the addition of fungal elicitor (Zimmermann et al. 1997). Some researchers have reported mitogen-activated protein kinase (MAPK) and G-protein activation responsible for elicitation. (Droillard et al. 2000; Agrawal et al. 2002).

Changes in protein phosphorylation pattern and protein kinase activation on elicitation have been reported during elicitation process (Felix et al. 1991; Yang et al. 1997; Romeis 2001 and Roos et al. 1999). Armero and Tena (2001) have suggested that acidification of cytoplasm caused by $\mathrm{H}^{+}$-ATPase inactivation could be involved in elicitation process. In elicitor treated plant tissues, decrease in membrane polarization and increase in extracellular $\mathrm{pH}$ has been considered for elicitation process (Pugin et al. 1997; Bolwell et al. 1995). Apostol et al. (1989) suggested that the production of ROS such as superoxide anion and $\mathrm{H}_{2} \mathrm{O}_{2}$ are responsible for elicitation process. This report has been supported by Low and Merida (1996) who observed that involvement of ROS in cross linking of cell wall bound protein rich components can act as a secondary messenger and it is involved in activation of defense genes. 
The demand of natural product is increasing proportionally due to medico clinical applications of plant products. However, the natural plant resources day by day are either in the threat or depleting. As a consequence, there is a possibility of creating a big vacuum with respect to the natural product produced and its increasing demands. Such situation reflects adversely two ways, the inadequate availability of essential bioactive plant product and the inflation in their cost. As a consequence, the utility of a particular product to the society is adversely affected and hence, the serious attentions are required to be paid by initiating the innovations and research in plant science that will contribute to fill up the lacunae to some extent if created in the future. The concept of secondary metabolite engineering is therefore, gained high importance since, it targets straight to the bioactive compounds. The present experimental work is a small effort towards this direction. The experimental system, Andrographis paniculata is cultivated in Ayurvedic nurseries due to its medicinal importance. When the supply of this particular plant resource is declined, the qualitative and quantitative enhancement of metabolite products by in vitro techniques remains the only way to obtain a desirable plant product.

\section{Conclusion}

The treatment duration is reported as an important criterion for the elicitation mechanism besides selection of suitable concentration of selected elicitors. Both the fungal elicitors ( $A$. niger and $P$. expansum) showed that longer treatment duration is suitable for eliciting andrographolide synthesis. This may be attributed to the presence of polysaccharides in the fungal extract for eliciting andrographolide when applied in moderate quantity.

\section{Abbreviations}

PAMP: Pathogen-associated molecular patterns; ROS: Reactive oxygen species; PDA: Potato dextrose agar; BAP: Benzyl amino purine.

\section{Competing interests}

Both authors declare that they have no competing interests.

\section{Authors' contributions}

Both the authors have equal contribution and both approved the final manuscript.

\section{Acknowledgement}

The authors are thankful to the Director, The Institute of Science, Mumbai for providing the analytical facilities.

Received: 16 September 2013 Accepted: 10 October 2013

Published: 24 October 2013

\section{References}

Ackerveken VG, Marois E, Bonas U (1996) Recognition of the bacterial avirulence protein AvrBs3 occurs insde the host plant cell. Cell 87:1307-1316

Agrawal GK, Rakwal R, Iwahashi H (2002) Isolation of novel rice (Oryza sativa L.) multiple stress responsive MAP kinase gene, OsMSRMK2, whose mRNA accumulates rapidly in response to environmental cues. Biochem Biophys Res Commun 294:1009-1016

Apostol L, Heinstein PF, Low PS (1989) Rapid stimulation of an oxidative burst during elicitation of cultured plant cells. Plant Physiol 190:109-116
Armero J, Tena M (2001) Possible role of plasma membrane $\mathrm{H}^{+}$-ATPase in the elicitation of phytoalexin and related isoflavone root secretion in chickpea (Cicer arietinum L.) seedlings. Plant Sci 161:791-798

Basse CW, Fath A, Boller T (1993) High affinity binding of a glycopeptide elicitor to tomato cells and microsomal membranes and displacement by specific glycan suppressors. J Biol Chem 268:14724-14731

Bojwani SS, Razdan MK (1996) Plant tissue culture: theory and practice, a revised edition. Elsevier, Netherland, p 539

Bolwell GP, Buti VS, Davies DR, Zimmerlin A (1995) The origin of the oxidative burst in plants. Free Radical Res 23:517-532

Braun DM, Walker JC (1996) Plant transmembrane receptors: new pieces in the signaling puzzle, Trends Biochem. Sci 21:70-73

Brodelius P, Funk C, Haner A, Villegas M (1989) A procedure for the determination of optimal chitosan concentrations for elicitation of cultured plant cells. Phytochemistry 28:2651-2654

Calabrese C, Berman SH, Babish JG, Ma X, Shinto L, Dorr M, Wells K, Wenner CA, Standish LJ (2000) A phase I trial of andrographolide in HIV positive patients and normal volunteers. Bastyr University Research Institute, Bastyr University, Washington 98028, USA. Phytother Res 14:333-338

Cheong JJ, Hahn MG (1991) A specific, high-affinity binding site for the heptaglucoside elicitor exists in soybean membranes. Plant Cell 3:137-147

Cosio EG, Frey T, Verduyn R, Boom JV, Ebel J (1990) High affinity binding of a synthetic heptaglucoside and fungal glucan phytoalexin elicitors to soybean membranes. FEBS Lett 271:223-226

Droillard MJ, Thibivilliers S, Cazale AC, Barbier BH, Lauriere C (2000) Protein kinases induced by osmotic stresses and elicitor molecules in tobacco cell suspensions: two crossroad MAP kinases and one osmoregulation-specific protein kinase. FEBS Lett 474:217-222

Ebel J, Scheel D (1997) The Mycota V, part A. In: Caroll GC, Tudzynski P (eds) Plant relationships. Springer, Berlin Heidelberg, pp 85-105

Felix G, Grosskopf DG, Regenass M, Boller T (1991) Rapid changes of protein phosphorylation are involved in transduction of the elicitor signal in plant cells. Proc Natl Acad Sci USA 88:8831-8834

Fu XQ, Lu DW (1999) Stimulation of shikonin production by combined fungal elicitation and in situ extraction in suspension cultures of Arnebia euchroma. Enzyme Microbial Technol 24:243-246

Gelli A, Higgins VJ, Blumwald E (1997) Activation of plant plasma membrane $\mathrm{Ca}^{2+}$-permeable channels by race specific fungal elicitors. Plant Physiol 113:269-279

Guava ViaCount Reagent (2006) Guava technologies, 4600-0010 rev c., pp 1-2

Hanania U, Avni A (1997) High-affinity binding site for ethylene-inducing xylanase elicitor on Nicotiana tabacum membranes. Plant J 12:113-120

Ibrahim AK, Khalifa S, Khafagi I, Youssef D, Khan I, Mesbah M (2007) Stimulation of oleandrin production by combined Agrobacterium tumefaciens mediated transformation and fungal elicitation in Nerium oleander cell cultures. Enzyme and Microbial Technology 41:331-336

Kumar RA, Sridevi K, Kumar NV, Nanduri S, Rajagopal S (2004) Anticancer and immunostimulatory compounds from Andrographis paniculata. J Ethnopharmacol 92:291-295

Low PS, Merida JR (1996) The oxidative burst in plant defense: function and signal transduction. Physiol Plant 96:533-542

Masanaru M (1994) Plant tissue culture an alternative for production of useful metabolites. FAO Bulletin, Rome, p 108

Mendhulkar VD, Ali Moinuddin M, Raut RW (2009) Saponin estimation in Vigna radiata cell culture treated with cell permeabilizing agent. Triton X-100 Advances in Plant Sciences 22:1-5, I

Murashige T, Skoog F (1962) A revised medium for rapid growth and bioassays with tobacco tissue cultures. Physiol Plant 15:473-497

Nürnberger T, Nennstiel D, Jabs T, Sacks WR, Hahlbrock K, Scheel D (1994) High affinity binding of a fungal oligopeptide elicitor to parsley plasma membranes triggers multiple defense responses. Cell 78:449-460

Pugin A, Frachisse JM, Tavernier E, Bligny R, Gout E, Douce R, Guern J (1997) Early events induced by the elicitor cryptogein in tobacco cells: involvement of a plasma membrane NADPH oxidase and activation of glycolysis and the pentose phosphate pathway. The Plant Cell 9(11):2077-2091

Purohit SS, Vyas SP (2004) Medicinal plant cultivation -a scientific approach. (Agrobios-India, publ.)., pp 307-309

Raskin I, Ribnicky DM, Komarnytsky S, llic N, Poulev A, Borisjuk N, Brinker A, Moreno DA, Ripoll C, Yakoby N, O'Neal JM, Cornwell T, Pastor I, Fridlender B (2002) Plants and human health in the twenty-first century. Trends Biotechnol 20:522-531 
Rates SMK (2001) Plants as sources of drugs. Toxicon 39:603-613

Romeis T (2001) Protein kinases in the plant defense response. Curr Opin Plant Biol 4:407-414

Roos W, Dordschbal B, Steighardt J, Hieke M, Weiss D, Saalbach G (1999) A redoxdependent, G-protein-coupled phospholipase A of the plasma membrane is involved in the elicitation of alkaloid biosynthesis in Eschscholtzia californica. Biochim Biophys Acta 1448:390-402

Sadasivam S, Manickam A (2005) Biochemical methods. New age international publishers, pp 10-11

Savitha BC, Thimmaraju R, Bhagyalakshmi N, Ravishankar GA (2006) Different biotic and abiotic elicitors influence betalain production in hairy root cultures of Beta vulgaris in shake-flask and bioreactor. Process Biochemistry 41:50-60

Vanisree M, Lee CY, Lo SF, Nalawade SM, Lin CY, Tsay HS (2004) Studies on the production of some important secondary metabolites from medicinal plants by plant tissue culture. Bot Bull Acad Sin 45:1-22

Yang Y, Gabriel DW (1995) Xanthomonas avirulence/pathogenicity gene family encodes functional plant nuclear targeting signals. Mol Plant Microbe Interact 8:627-631

Yang J, Yu M, January YN, January LY (1997) Stabilization of ion selectivity alters by pore loop ion pairs in an inwardly rectifying potassium channel. Proc Natl Acad Sci USA 94:1568-1572

Zhang CH, Mei XG, Liu L, Yu LJ (2000) Enhanced paclitaxel production induced by the combination of elicitors in cell suspension cultures of Taxus chinensis. Biotechnology Letters 22:1561-1564

Zhao HY, Frang WY (1991) Antithrombotic effect of Andrographis paniculata Nees in preventing myocardial infarction. Chi Med J (Engl) 104:770-775

Zimmermann S, Nürnberger T, Frachisse JM, Wirtz W, Guern J, Hedrich R, Scheel D (1997) Receptor-mediated activation of a plant Ca21-permeable ion channel involved in pathogen defense. Proc Natl Acad Sci USA 94:2751-2755

doi:10.1186/1999-3110-54-49

Cite this article as: Vakil and Mendhulkar: Enhanced synthesis of andrographolide by Aspergillus niger and Penicillium expansum elicitors in cell suspension culture of Andrographis paniculata (Burm. f.) Nees. Botanical Studies 2013 54:49

\section{Submit your manuscript to a SpringerOpen ${ }^{\circ}$ journal and benefit from:}

- Convenient online submission

- Rigorous peer review

- Immediate publication on acceptance

- Open access: articles freely available online

- High visibility within the field

- Retaining the copyright to your article

Submit your next manuscript at $\gg$ springeropen.com 